\title{
Influence of the innovative prebiotic complex on physiological state of pigs and quality indicators of pork
}

\author{
Marina Slozhenkina, Ivan Gorlov, Alexei Miroshnik, and Dmitriy Nikolaev \\ Volga Region Research Institute of Manufacture and Processing of Meat-And-Milk Production, Volgograd, Russia
}

\begin{abstract}
The article presents an analysis of the use of antibiotic therapy in pig breeding and offered an alternative to them in the form of prebiotic supplements. Studies were conducted on the effect of probiotic drugs on the body of large white pigs in the farm-breeding plant Named after Lenin of Surovikinsky District of Volgograd Region and lasted until 180 days of age. For the experiment, 2 groups of Large White piglets of 2 months of age were formed. Each experimental group consisted of 15 pigs. Animals of the control group received standart farm animal diet $(\mathrm{SD})$, analogs of the first experimental group - SD + mixture of dietary supplements "LactuVet-1" and "Chlorelact" at a dosage of $0.2 \mathrm{mg} / \mathrm{kg}$ of live weight each. Deep studies were conducted on the effect of probiotic supplements to live weight gain, natural resistance, immunoglobulin reactivity, and slaughter indicators of piglets. Superiority of pigs from the experimental group in almost all the studied indicators over the peers of the control group was established.
\end{abstract}

\section{Introduction}

Modern farm animals and poultry are the result of selection for fertility and early maturity, which led to decrease in resistance, adaptive plasticity to massive occurrence of stress maladjustments with immunodeficiency syndromes. Thereby, low level of immunological reactivity and natural resistance have made farm animals especially susceptible to such stress factors as chemical pressure, in particular, the use of antibiotics and other antibacterial drugs.

According to studies, introduction of antibiotics for preventive purposes, along with protecting the body from diseases of various etiologies, disrupts intestinal microflora normal biocenosis of the animal body and leads to a deterioration in digestive processes, which causes a significant decrease in meat productivity [1-12].

At the same time, the negative consequences of such pharmacological pressure, strengthened by anthropogenic and technogenic load on farm animals habitat, over time are expressed in increased variability and, consequently, the development of multiple drug resistance and increased pathogenicity factors in bacteria and viruses circulating in farms [13-18].

This is the reason for enormous scientific and practical interest in the problem of replacing antibiotic substances, including by prebiotics - promising biologically active substances used to regulate microbiological processes, prevent and treat alimentary and infectious diseases of gastrointestinal tract [19-22].

Prebiotic drugs based on lactulose have recently gained widespread use. This substance is the only low molecular weight carbohydrate of animal origin. Lactulose has bifidogenic properties, and slows down the formation of ammonia in animal's body, which prevents hyperammonemia and reduces the load on the liver. A small amount of lactulose $-0.25-2.00 \%$ of feed weight, can be absorbed in the gastrointestinal tract, causing an immunological effect. Recent studies carried out on rats have shown a positive effect of lactulose on the absorption of calcium and magnesium [13, 23-31].

Thus, the foregoing indicates that lactulose-based feed additives are promising and effective dietary correctors for farm animals. Such feed additives are being actively studied from the viewpoint of improving productivity of pigs and in-vivo formation of consumer properties of meat [30-34].

This is especially important in light of achieving the country's food security, which, of course, is a strategic task facing agro-industrial complex of the Russian Federation [35-44].

The purpose of the work is to study the complex effect of biologically active additives "LactuVet-1" and "Chlorelact" on slaughter indicators of pigs and quality of muscle tissue.

\section{Materials and methods}

The scientific studies were carried out on the basis of farm-breeding plant Named after Lenin of Surovikinsky District of Volgograd Region in 2020. For the experiment, 2 groups of Large White piglets of 2 months of age were formed. Each experimental group consisted of 15 pigs.

Animals of the control group received standart farm animal diet (SD), analogs of the experimental group - SD + mixture of dietary supplements "LactuVet-1" and "Chlorelact" at a dosage of $0.2 \mathrm{mg} / \mathrm{kg}$ of live weight each.

The animals were fed complete feeds according to their physiological needs. Feeding was carried out twice 
in the morning and in the evening, access to water was free. The experiment lasted until 180 days of age, after which a control slaughter was carried out and longissimus dorsi was obtained from 6 animals from each group. Sampling and organoleptic assessment were carried out in accordance with GOST 9959-2015 "Meat and meat products. General conditions for carrying out sensory evaluation". Morphological composition was studied on right half carcasses 24 hours after slaughter by complete deboning.

The assessment of the physiological state of the experimental young animals was studied on the basis of the content of erythrocytes and leukocytes in the blood of the pigs, which were determined by the counting method in the Goryaev's chamber, hemoglobin - according to Sali, total protein in the blood serum - by refractometric method, separation into protein indicators - using the electrophoresis technique modified by Yudelovich, calcium - according to De Waard, phosphorus - according to Briggs.

Natural resistance was studied on the basis of absorption and digestion capacity of neutrophils and assessment of phagocytic activity.

Determination of immunoglobulins of individual isotypes content was determined in triplicate by the method of radial immunodiffusion according to Mancini using special antisera and monoclonal antibodies for certain classes of immunoglobulins and reference serum (Bem E., 1953).

All results, obtained in the research were processed by the methods of variation statistics using STATISTICA-6 software package and determining the reliability criterion of the difference according to Student-Fisher at three levels of probability.

\section{Results and Discussions}

Growth and development of animals is directly related to nutrients absorption level by the body. Enhancement of metabolic processes in pigs body can be indirectly confirmed on the basis of hematological parameters.

Protein, fat, calcium and phosphorus content in the blood of piglets changes depending on the feeding of various feeds. The process of deamination of amino acids in the blood of pigs proceeds with the use of energy and release of nitrogen, which is subsequently excreted by kidneys from the body.

As a result of the experiment, it was found that in terms of total protein content in the blood of experimental pigs, the animals of the experimental group exceeded the analogs of the control group by $1.76 \mathrm{~g} / 1$, or $1.44 \%$; albumin - by $0.98 \mathrm{~g} / 1$, or $1.82 \%$; globulins - by $2.31 \mathrm{~g} / 1$, or $4.36 \%(\mathrm{P} \leq 0.05) ; \alpha$-globulins - by $0.64 \mathrm{~g} / 1$, or $3.43 \%$ $(\mathrm{P} \leq 0.05) ; \gamma$-globulins - by $1.27 \mathrm{~g} / 1$, or $4.37 \%$.

In the course of the experiment, it was found that content of total protein and its fractions in piglets' blood from the experimental group were increased. This suggests an increased metabolism of lipids, endocrine glands, biological pigments and minerals, occurring in tissues and organs of animal's body.
To determine the level of immune protection of the pig body, great importance is given to the content of formed elements in the blood serum: red blood cells, white blood cells, hemoglobin; which correlate with natural resistance of their body (table 1).

Table 1. Results of hematological studies of blood obtained from experimental pigs $(n=6)$.

\begin{tabular}{|c|c|c|c|}
\hline \multirow{2}{*}{ Index } & \multirow{2}{*}{$\begin{array}{l}\text { Norm for } \\
\text { piglets }\end{array}$} & \multicolumn{2}{|c|}{ Group } \\
\hline & & control & experimental \\
\hline Erythrocytes, $10^{12 / 1}$ & $6.00-7.50$ & $6.35 \pm 0.02$ & $7.12 \pm 0.01 * * *$ \\
\hline Leukocytes, $10^{9} / 1$ & $8.00-16.00$ & $9.24 \pm 0.03$ & $10.35 \pm 0.02 * * *$ \\
\hline Hemoglobin, g / 1 & $99.0-119.0$ & $103.89 \pm 0.71$ & $108.18 \pm 0.69 * *$ \\
\hline $\begin{array}{c}\text { Erythrocyte } \\
\text { sedimentation rate, } \\
\mathrm{mm} / \mathrm{h}\end{array}$ & $2.0-9.0$ & $2.64 \pm 0.24$ & $3.72 \pm 0.38$ \\
\hline
\end{tabular}

It was found that the blood of pigs in the experimental group contained more erythrocytes than in the control group, by $0.7710^{12} / 1$, or $12.12 \%(\mathrm{P} \leq 0.001)$; leukocytes by $1.1110^{9} / 1$, or $12.01 \%(\mathrm{P} \leq 0.001)$; hemoglobin - by $4.29 \mathrm{~g} / \mathrm{l}$, or $4.13 \%(\mathrm{P} \leq 0.01)$; ESR - by $1.08 \mathrm{~mm} / \mathrm{h}$, or $40.91 \%$.

From the experimental results obtained, it can be concluded that the studied animals were clinically healthy, since all indicators did not exceed the physiological norm. However, the higher results shown in piglets of the experimental group can be considered an indirect confirmation of a high level of resistance in comparison with analogs of the control group. To assess the level of resistance of experimental piglets, the following analyses and calculations were performed (table 2).

Table 2. Assessment of the natural immunity of experimental pigs $(n=6)$.

\begin{tabular}{|l|c|c|}
\hline \multicolumn{2}{|c|}{ Index } & \multicolumn{2}{c|}{ Group } \\
\cline { 2 - 3 } & control & experimental \\
\hline Lysozyme, $\mu \mathrm{g} \%$ & $18.84 \pm 0.17$ & $19.35 \pm 0.19$ \\
\hline Attraction for 50 neutrophils, $\%$ & $21.37 \pm 0.22$ & $21.62 \pm 0.24$ \\
\hline $\begin{array}{l}\text { The number of phagocytic } \\
\text { neutrophils, } \%\end{array}$ & $23.84 \pm 0.23$ & $25.86 \pm 0.27 * *$ \\
\hline Phagocytic index, \% & $5.36 \pm 0.08$ & $5.51 \pm 0.11$ \\
\hline
\end{tabular}

As can be seen from the data in table 2, natural resistance of piglets from the experimental group was higher compared to the analogues of the control group. The number of phagocytic neutrophils in them is higher by $2.02 \%(\mathrm{P} \leq 0.01)$, and the lysozyme activity - by $0.51 \%$, attraction of 50 neutrophils - by $0.25 \%$ and phagocytic index - by $0.15 \%$.

The resistance of the body under the impact of respiratory infections is formed depending on cellular and humoral reactions of immune system. Such a system was formed due to the action of two active conglomerates of lymphocytes: first consists of B cells that can form antibodies; second consists of $\mathrm{T}$ cells that directly regulate cell-type reactions.

During the experiment, the most pronounced response of the immune system was obtained by analyzing blood of the animals from the experimental group that received 
prebiotic drugs, compared with animals from the control group.

The analysis of colostral antibodies content was performed on the blood serum of piglets at the age of 150 days to determine content of passive and acquired immunoglobulins.

Experimental studies have shown that pigs of the experimental group exceeded the control group analogues in content of $\operatorname{IgG}$ and $\operatorname{IgA}$-isotypes in serum by 0.89 $\mathrm{mg} / \mathrm{ml}$, or $9.24 \%(\mathrm{P} \leq 0.05)$, and $0.24 \mathrm{mg} / \mathrm{ml}$, or $19.54 \%$ $(\mathrm{P} \leq 0.05)$.

Thus, the introduction of lactulose-containing feed additives contributed to an increase in concentration of immunoglobulins IgG and IgA-isotypes, which, on the one hand, is associated with a higher accumulation of antibodies to various bacteria and viruses, and, on the other hand, with a response to various infectious diseases. All this indicates an increase in antibacterial protection of the pigs body.

At the end of the experiment, control slaughter was carried out. Slaughter qualities of pork carcasses are shown in table 3 .

Table 3. Slaughter qualities of experimental pigs live weight of $100 \mathrm{~kg}(\mathrm{n}=6)$.

\begin{tabular}{|c|c|c|}
\hline \multirow{2}{*}{ Index } & \multicolumn{2}{|c|}{ Group } \\
\hline & control & experimental \\
\hline $\begin{array}{l}\text { The area of "muscular } \\
\text { eye", } \mathrm{cm}^{3}\end{array}$ & $32.85 \pm 0.43$ & $35.05 \pm 0.15^{* *}$ \\
\hline Internal fat weight, $\mathrm{kg}$ & $2.01 \pm 0.08$ & $2.17 \pm 0.13$ \\
\hline $\begin{array}{l}\text { Weight of the rear } \\
\text { third of half carcass, } \\
\mathrm{kg}\end{array}$ & $10.92 \pm 0.57$ & $11.46 \pm 0.49$ \\
\hline \multicolumn{3}{|c|}{ Proportion in the meat carcass, kg: } \\
\hline muscle tissue & $61.12 \pm 0.32$ & $61.28 \pm 0.24$ \\
\hline adipose tissue & $25.99 \pm 0.20$ & $25.82 \pm 0.22$ \\
\hline bone tissue & $12.89 \pm 0.28$ & $12.90 \pm 0.18$ \\
\hline
\end{tabular}

From the data presented, it can be seen that in pork carcasses of the experimental group, proportion of muscle to adipose tissue was higher by $0.9 \%$, internal fat - by 0.16 $\mathrm{kg}$, or $8.0 \%$. It is also possible to declare an increase in the area of "muscle eye" by $2.2 \mathrm{~cm}^{3}$, or $7.0 \%$. Structure characteristics of longissimus dorsi muscle of experimental pigs are shown in table 4.

Table 4. Technological parameters of longissimus dorsi muscle $(\mathrm{n}=6)$.

\begin{tabular}{|c|c|c|c|c|}
\hline \multirow[b]{2}{*}{ Group } & \multicolumn{3}{|c|}{ Type of tissue, \% } & \multirow{2}{*}{$\begin{array}{l}\text { The } \\
\text { protein } \\
\text { quality } \\
\text { indicator }\end{array}$} \\
\hline & muscle & $\begin{array}{c}\text { connectiv } \\
\mathrm{e}\end{array}$ & $\begin{array}{c}\text { adipos } \\
\mathrm{e}\end{array}$ & \\
\hline Control & $\begin{array}{c}87.1 \pm 0 . \\
4\end{array}$ & $8.5 \pm 0.3$ & $\begin{array}{c}4.4 \pm 0 \\
1\end{array}$ & 9.41 \\
\hline $\begin{array}{c}\text { Experimenta } \\
1\end{array}$ & $\begin{array}{c}87.7 \pm 0 . \\
1\end{array}$ & $8.4 \pm 0.4$ & $\begin{array}{c}3.9 \pm 0 . \\
4\end{array}$ & 9.57 \\
\hline
\end{tabular}

There were no significant differences in structural features of longissimus dorsi muscle. At the same time, the protein-quality index of the muscle in pigs of the experimental group is $1.7 \%$ higher, which in most cases also corresponds to an increase in the share of essential amino acids and indicates a higher protein value of meat.
In order to determine the nature of autolysis, one hour and one day after slaughter, organoleptic assessment and measurements of the $\mathrm{pH}$ of obtained pork were made. The results are shown in figure.

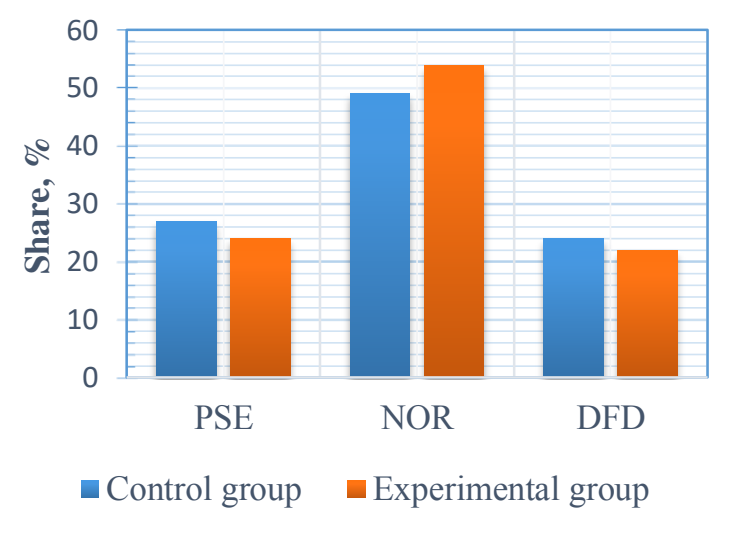

Fig 1. Share of defective pork meat $(n=6)$.

Increase in the proportion of muscle tissue characterized by absence of PSE and DFD defects and $\mathrm{pH}$ values within 5.6-6.2 $\mathrm{pH}$ in animals of the experimental group was noted. Such meat is obtained from animals with normal development of autolytic processes in the animal body, has better organoleptic and technological characteristics, which means a wider range of applications in meat processing.

\section{Conclusion}

The introduction of the innovative prebiotic complex of biologically active additives "LactuVet-1" and "Chlorelact" into the feeding of pigs in comparison with the standard fattening technology had a positive effect on physiological state and level of humoral immunity of animals. We explain this effect of increased bactericidal, lysozyme and phagocytic activity due to intensification of processes of erythropoiesis, lymphocytopoiesis in the gastrointestinal tract under influence of the prebiotic complex.

The results of the control slaughter also indicate an improvement of slaughter qualities of the experimental group pigs. The area of the "muscular eye", weight of the rear third of half carcass and proportion of muscle tissue in carcass were significantly higher.

Analysis of technological qualities showed a decrease in proportion of DFD and PSE meat and superiority in level of protein-quality indicator of muscle tissue of animals from the experimental group. This indicates higher quality and profitability the pork.

\section{Acknowledgments}

This work was carried out under the grant of the Russian Science Foundation 21-16 00025 SSI NIIMMP. Grant sponsors were not directly involved in the development, analysis, or writing of this article. The authors would like to thank their colleagues for their contribution and support to the research. They are also thankful to all the reviewers 
who gave their valuable inputs to the manuscript and helped complete the paper.

\section{References}

1. M.I. Zadera, A.K. Gruzdeva, Using of antibiotics in cultivation of farm animals. Antibiotics in agricultural products, Young scientist, 19, 20 (2018)

2. C.J. Hedegaard, P.M.H. Heegaard, Vet. Immunol. Immunopathol. 174, 50-63 (2016). DOI: 10.1016/j.vetimm.2016.04.007

3. A.A. Shevtsov, V.S. Rusaleev, F.A. Shiryaev, A.V. Potekhin, Pigbreeding, 4, 31 (2008)

4. Z. Tian, Y. Cui, H. Lu, G. Wang, X. Ma, Meat Sci. 171, $\quad 108234$

(2021).

DOI 10.1016/j.meatsci.2020.108234

5. Baumann S, Schoof S, Bolten M, Haering C, Takagi M, Shin-Ya K, Arndt H, J. Am. Chem. Soc. 132, 6973 (2010)

6. Gorlov I, Sitnikov V, Shkalenko A, Sivko A, I. Bushueva, Pigbreeding 2, 16-17 (2007)

7. D.Yu. Makarov, F.V. Ruzheinikov, V.V. Shkalenko, D.V. Nikolaev Pigbreeding 5, 61-62 (2012)

8. K.D. Sinclair, K.M. Rutherford, J.M. Wallace, J.M. Brameld, R. Stoger, R. Alberio, D. Sweetman, D.S. Gardner, V.E. Perry, C.L. Adam, C.J. Ashworth, J.E. Robinson, C.M. Dwyer, Reprod. Fertil. Dev. 28, 1443-1478 (2016). DOI: 10.1071/RD16102

9. L.A. Neminuschaya, O.V. Provotorova, N.K. Eremets, A.A. Nezhuta, P.A. Krasochko, Veterinaria i kormlenie, 6, 21 (2014)

10. C. Rojo-Gimeno, M. Postma, J. Dewulf, H. Hogeveen, L. Lauwers, E. Wauters, Prev. Vet. Med., 129, 74-87

DOI: 10.1016/j.prevetmed.2016.05.001

(2016).

11. F. Aarestrup, Nature, 486, 465-466 (2012). DOI: $10.1038 / 486465 \mathrm{a}$

12. L.V. Alarcon, A.A. Alberto, E. Mateu, Porc. Health Manag., 7, 24 (2021). DOI: 10.1186/s40813-02000181-z

13. D.V. Usenko, Medical Council, 16, 98 (2016)

14. F. Blasi, C. Lovito, E. Albini, L. Bano, G. Dalmonte, I. Drigo, C. Maresca, F.R. Massacci, S. Orsini, S. Primavilla, E. Scoccia, S. Tofani, C. Forte, C.F. Magistrali, Animals, 11, 1-15 (2021). DOI: $10.3390 /$ ani11020515

15. C. Liu, P. Wang, Y. Dai, Y. Liu, Y. Song, L. Yu, C. Feng, M. Liu, Z. Xie, Y. Shang, S. Sun, F. Wang, Poult. Sci. J., 100, 100887 (2021). DOI: $10.1016 / j . p s j .2020 .11 .064$

16. P.D. Fowler, S. Sharma, D.K. Pant, S. Singh, M.J. Wilkins, Vet. World, 14, 437-445 (2021). DOI: $10.14202 /$ vetworld.2021.437-445

17. C. Viana, J.L. Grossi, M.J. Sereno, R.S. Yamatogi, L.D.S. Bersot, D.R. Call, L.A. Nero, Int. Food Res. J., 137, $109406 \quad$ (2020). DOI: $10.1016 /$ j.foodres.2020.109406
18. H. Nikaido, Annu. Rev. Biochem., 78, 119-146 (2009).

DOI: 10.1146/annurev.biochem.78.082907.145923

19. G. López-Gálvez, M. López-Alonso, A. Pechova, B. Mayo, N. Dierick, J. Gropp, Anim. Feed Sci. Technol., 271, $114727 \quad$ (2021). DOI: $10.1016 /$ j.anifeedsci.2020.114727

20. D. Shin, S.Y. Chang, P. Bogere, K. Won, J.Y. Choi, Y.J. Choi, H.K. Lee, J. Hur, B. Park, Y. Kim, J. Heo, PLoS ONE, 14, e0220843 (2019). DOI: $10.1371 /$ journal.pone. 0220843

21. A.A.A. Abdel-Wareth, S. Hammad, R. Khalaphallah, W.M. Salem, J. Lohakare, Poult. Sci. J., 98, 45757583 (2019). DOI: 10.3382/ps/pez115

22. A. Chlebicz-Wojcik, K. Slizewska, Animals, 10, 118 (2020). DOI: 10.3390/ani10111999

23. S.A. Ryabtseva, A.G. Khramtsov, R.O. Budkevich, G.S. Anisimov, A.O. Chuklo, M.A. Shpak, Problems of Nutrition, 89, 5 (2020)

24. M. Nooshkam, A. Babazadeh, H. Jooyandeh, Trends Food Sci. Technol. 80, 23 (2018)

25. J. Xin, D. Zeng, H. Wang, N. Sun, Y. Zhao, Y. Dan, K. Pan, B. Jing, X. Ni, Probiotics and Antimicrobial Proteins 12, 184 (2020)

26. V. Kryukov, I. Glebova, S. Zinoviev, A. Shevyakov, Compound feeds, 3, 90 (2018)

27. A.G. Khramtsov, S.A. Ryantseva, R.O. Budkevich, V.R. Akhmedova, A.B. Rodnaya, E.V. Marugina, Problems of nutrition, 875 (2018)

28. L.B. Bindels, N.M. Delzenne, P.D. Cani, J. Wolter, Nature reviews, 12, 303 (2015)

29. E.D. Sonnenburg, H. Zheng, P. Joglekar, S.K. Higginbottom, S.J. Firbank, D.N. Bolam, J.L. Sonnenburg, Cell, 141, 1241-1252 (2010). DOI: 10.1016/j.cell.2010.05.005

30. S.I. Nikolaev, G.V. Volkolupov, V.I. Vodyannikov, V.V. Shkalenko, Izvestia of the Lower Volga AgroUniversity Complex, 2 147-152 (2016)

31. A.S. Miroshnik, M.I. Slozhenkina, I.F. Gorlov, M.V. Frolova, D.V. Nikolaev, N.I. Mosolova, IOP Conf. Ser.: Earth Environ. Sci. 677, 032009 (2021). DOI: $10.1088 / 1755-1315 / 677 / 3 / 032009$

32. B. Landwehr, Efficient animal husbandry, 8, 11-13 (2019)

33. O.A. Bagno, O.N. Prokhorov, S.A. Shevchenko, A.I. Shevchenko, T.V. Dyadichkina, Agricultural Biology, 53, 687-697 (2018). DOI: 10.15389/agrobiology.2018.4.687eng

34. M. Kenny, H. Smidt, E. Mengheri, B. Miller, Animal, 5, 462-470 (2011). DOI: $10.1017 / \mathrm{S} 175173111000193 \mathrm{X}$

35. A.V. Buyarov, V.S. Buyarov, Bulletin of agrarian science, 63, 80-92 (2016)

36. E.V. Stepanova, Azimuth of scientific research: economics and administration, 2, 319-322, (2020). DOI: 10.26140/anie-2020-0902-0075

37. V. Glinskiy, L. Serga, M. Alekseev, N. Samotoy, E. 
Simonova, Procedia Manufacturing, 21, 838-845 (2018). DOI: 10.1016/j.promfg.2018.02.191

38. G.A. Iovlev, I.I. Goldina, V.S. Zorkov, E3S Web of Conferences, 222, $3014 \quad$ (2020). DOI: $10.1051 / \mathrm{e} 3 \mathrm{sconf} / 202022203014$

39. Y.V. Melnikova, A.V. Shokhnekh, Lecture Notes in Networks and Systems, 87, 809-816 (2020). DOI: 10.1007/978-3-030-29586-8_92

40. Y. Shafieva, A. Maksimenko, E3S Web of Conferences, 210, $10003 \quad$ (2020). DOI: $10.1051 / \mathrm{e} 3 \mathrm{sconf} / 202021010003$

41. I. Boldyreva, O. Andryushchenko, A. Nikitaeva, Z. Udalova, J. Rudash, J. Environ. Manag. Tour., 8, 642-647 (2017). DOI: 10.14505/jemt.v8.3(19).15

42. V. Sedykh, G. Pyrchenkova, E. Radchenko, IOP Conference Series: Earth and Environmental Science, 548, 1 (2020). DOI: 10.1088/17551315/548/8/082031

43. L. Kopteva, I. Romanova, J. Adv. Res. Law Econ., 10, 1898-1906

(2019). DOI: $10.14505 /$ jarle.v10.6(44).32

44. A. Ulezko, A. Tyutyunikov, A. Kurnosov, IOP Conference Series: Earth and Environmental Science, 274, 012063 (2019). DOI: 10.1088/1755$1315 / 274 / 1 / 012063$ 